\title{
THE EFFECT OF TEMPERATURE AND SCARIFICATION METHOD ON GORSE (ULEX EUROPAEUS L.) SEED GERMINATION
}

\author{
C.R. SIXTUS, G.D. HILL and R.R. SCOTT \\ Soil, Plant and Ecological Sciences Division, PO Box 84, \\ Lincoln University, Canterbury \\ Corresponding author: sixtusc1@lincoln.ac.nz
}

\begin{abstract}
As part of a study of gorse (Ulex europaeus L.) biocontrol, the scarification requirements to maximise germination of freshly harvested seed were investigated. Both time of immersion in concentrated sulphuric acid $(36 \mathrm{~N})$ and incubation temperature were critical. Optimum incubation temperature was $15^{\circ} \mathrm{C}$ (mean germination $65 \%$ ). The sulphuric acid treatments that gave the highest percentage of germinated seeds were 180 and $210 \mathrm{~min}$ immersion with incubation at $15^{\circ} \mathrm{C}$, giving a mean germination of $81 \%$. The mean control germination, over all incubation temperatures, was $10 \%$. Hot water immersion did not significantly increase germination when compared with the unscarified control treatment. Mechanical scarification gave a mean germination over all temperatures of $35 \%$; the highest germination was again at $15^{\circ} \mathrm{C}(48 \%)$.
\end{abstract}

Keywords: gorse, germination temperature, acid scarification, mechanical scarification.

\section{INTRODUCTION}

Gorse (Ulex europaeus L.) is a prolific seeder and seed viability is at least 40 years (Zabkiewicz 1976; Zabkiewicz \& Gaskin 1978). There is anecdotal evidence that hardcoated seed may lie ungerminated in the soil for 75 years (W.J. Davis, pers. comm.). The ability of gorse seed to remain viable for many years, just requiring to be brought nearer the surface for germination to occur, means that the weed seedbank can rapidly re-establish gorse infestations (Ivens 1982).

Scarification with concentrated sulphuric acid $\left(\mathrm{H}_{2} \mathrm{SO}_{4}\right)(36 \mathrm{~N})$ may increase gorse seed germination. In Russell lupin (Lupinus polyphyllus $\mathrm{x}$ L. arboreus) acid scarification for 30 or 45 min gave more than $75 \%$ germination, while unscarified control seed had $20 \%$ germination (Tesfaye 1989). With broom (Cytisus scoparius) highest germination was obtained from seed that had been immersed in $\mathrm{H}_{2} \mathrm{SO}_{4}$ for $5 \mathrm{~h}$ (Wan Mohamed 1981). In one experiment with concentrated $\mathrm{H}_{2} \mathrm{SO}_{4}$ and gorse seed, the highest germination was obtained after $60 \mathrm{~min}$ of immersion followed by a 21-day incubation (Butler 1976). In a previous study of gorse seed, the best constant temperature for germination was $15^{\circ} \mathrm{C}$ (Moss 1959). However, the optimum temperature for scarified seed germinated in light was $16^{\circ} \mathrm{C}$. The germination rate declined at temperatures above optimum (Zabkiewicz $\&$ Gaskin 1978). Another study showed the optimum constant temperature range for germination of gorse seed was $15-19^{\circ} \mathrm{C}$ (Ivens 1983). Butler (1976) found more seed germinated under alternating temperatures between 15 and $20^{\circ} \mathrm{C}$ for 19 weeks than untreated seeds kept at $20^{\circ} \mathrm{C}$ for 17 weeks.

This study is part of a program that is determining the proportion of gorse seeds that are hard or dead to establish why some gorse seeds are not germinating. These experiments measured the amount of gorse seed that germinated under laboratory conditions with differing temperature, concentrated sulphuric acid, hot water and mechanical scarification 
treatments. The best scarification method and temperature for gorse seed germination will be used in the laboratory to test gorse viability throughout the South Island, New Zealand.

\section{MATERIALS AND METHODS}

Gorse seed was collected from plants growing at Onekaka, Golden Bay, New Zealand, site reference $40^{\circ} 46.31 \mathrm{~S}, 172^{\circ} 43.49 \mathrm{E}$, altitude $68 \mathrm{~m}$. The seed for Experiment 1 was collected on 20 September 2002 and for Experiment 2 on 17 November 2002. Only mature brown pods were collected. Until required the seed was stored in the pods in a refrigerator at $4^{\circ} \mathrm{C}$. When required for testing, the pods were dried at $60^{\circ} \mathrm{C}$ for $24-48 \mathrm{~h}$ then threshed in a Kurt Peltz thresher. After threshing, the seed was washed and any that floated or appeared shrivelled were discarded. The seed was carefully examined to exclude any seed that had been attacked by Cydia succedana or Exapion ulicis, which are both insects that feed on gorse seed.

All equipment was sterilised in an autoclave and only sterilised water was used. To further minimise the risk of infestation by fungi and bacteria, seed samples were washed in $2.5 \%$ sodium hypochlorite $(\mathrm{NaOCl})$ for $5 \mathrm{~min}$. The seed was then rinsed and air-dried overnight at room temperature.

\section{Incubation temperature}

The incubator temperatures used in both experiments were a constant 5, 10, 15, 20 or $25^{\circ} \mathrm{C}$. Seed was germinated for 10 days. For each treatment, 25 seeds were placed on a moist germination paper in a Petri dish. There were four replicates at each temperature of each scarification treatment. Dishes were inspected daily and sterilised water added as required. The incubators were operated with $16 \mathrm{~h}$ light and $8 \mathrm{~h}$ dark cycle.

\section{Experiment 1: Acid scarification}

Two volumes of acid to one volume of seed were used (Hartmann et al. 2002). Seed samples were placed in concentrated sulphuric acid (36N) for 0 (control), 30, 60, 90, $120,150,180,210,240,270$ or 300 min. Following acid treatment seed was washed in running water until the $\mathrm{pH}$ was neutral, and then rinsed in sterile water. After rinsing, the seeds were placed in Petri dishes.

\section{Experiment 2: Hot water and mechanical scarification}

Surface-sterilised seed was immersed in hot water at $70,75,80,85,90,95$ or $100^{\circ} \mathrm{C}$ for 1, 2 and $5 \mathrm{~min}$. Following hot water immersion, the seed was rapidly cooled by placing it under running cold water. Control seed was only surface sterilised. Another set of seeds was mechanically scarified by placing them in a sealed tobacco tin lined with fine sandpaper through which compressed air was pumped for 10 seconds (R.J. Lucas, pers. comm.). After scarification treatments, the seeds were placed in the Petri dishes.

\section{Data collection and statistical analysis}

The number of seeds germinated was counted 10 days after scarification. A seed was counted as germinated when it showed a radicle that was at least the length of the seed. Seedlings were not classified as normal and abnormal. Data were analysed using analysis of variance with the GENSTAT for Windows (release 6) package.

\section{RESULTS}

\section{Experiment 1: Acid scarification}

Gorse seed required both acid scarification and incubation temperatures of up to $15^{\circ} \mathrm{C}$ to obtain good germination. Germination temperatures above $15^{\circ} \mathrm{C}$ reduced germination; at $25^{\circ} \mathrm{C}$ the mean germination was only $8.9 \%$ (Table 1 ). 
TABLE 1: The mean germination of gorse seed (\%) after 10 days at different constant germination temperatures, after scarification in concentrated sulphuric acid (36N) for between 0 and $300 \mathrm{~min}$.

\begin{tabular}{ccc}
\hline Temperature $\left({ }^{\circ} \mathrm{C}\right)$ & Mean Germination $(\%)$ & SE \\
\hline 5 & 45.9 & 0.011 \\
10 & 62.6 & 0.020 \\
15 & 64.9 & 0.022 \\
20 & 36.5 & 0.011 \\
25 & 8.9 & 0.011 \\
\hline
\end{tabular}

Germination increased with increased time in acid (Table 2). The highest germination was after 180 and $210 \mathrm{~min}$ in acid with $81 \%$ germination at the optimum incubation temperature of $15^{\circ} \mathrm{C}$ (Fig. 1).

TABLE 2: $\quad$ Mean germination of gorse seed (\%) after different times of immersion in concentrated sulphuric acid averaged over all incubation temperatures.

\begin{tabular}{ccc}
\hline Immersion in acid (min) & Mean germination & SE \\
\hline 0 & 10.2 & 0.032 \\
30 & 40.4 & 0.034 \\
60 & 46.0 & 0.028 \\
90 & 48.6 & 0.036 \\
120 & 57.0 & 0.043 \\
150 & 49.6 & 0.044 \\
180 & 49.6 & 0.039 \\
210 & 50.6 & 0.031 \\
240 & 47.2 & 0.023 \\
270 & 40.0 & 0.032 \\
300 & 42.8 & 0.032 \\
\hline
\end{tabular}

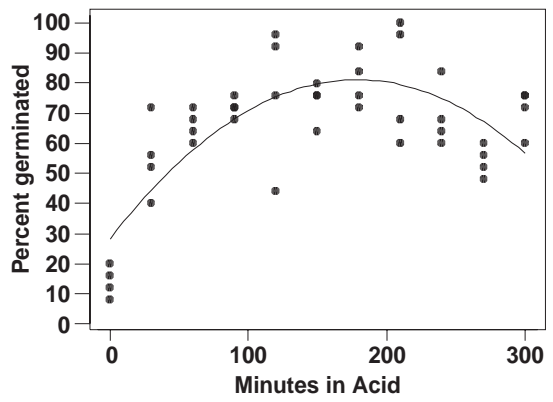

FIGURE 1: Germination of gorse seed $(\%)$ in response to time of immersion in sulphuric acid when germinated at $15^{\circ} \mathrm{C}$ for 10 days. Individual Petri dishes are represented by dots and the line shows the predicted percentage of germinated seed. The regression equation for this line is: Percentage germination $=28.2+0.594(\mathrm{~min}$ in acid $)-0.00167(\mathrm{~min}$ in acid $)^{2}, S=13.9, R^{2}=58.6 \%, R^{2}(\operatorname{adj})=56.6 \%$.

None of the hot water treatments increased germination significantly over the unscarified control seed. Mechanical scarification gave a germination of $35 \%$, which was significantly different $(\mathrm{P}<0.001)$ from unscarified seed, which had a germination of $10 \%$. 


\section{DISCUSSION}

These experiments were conducted in order to find the method of scarification and temperature that would cause hard seeds to germinate. Previous studies of gorse seed reported that scarification or heat enhances germination (Zabkiewicz \& Gaskin 1978; Ivens 1983). Experiment 1 showed that acid scarification significantly increased seed germination. It also indicated that the optimum temperature for acid scarified gorse seed germination was about $15^{\circ} \mathrm{C}$, with germination declining above $15^{\circ} \mathrm{C}$. Ivens (1983) found that the optimum temperature for germination was $18^{\circ} \mathrm{C}$ and then the germination decreased up to $26^{\circ} \mathrm{C}$; above $26^{\circ} \mathrm{C}$ germination was inhibited. Experiment 2 showed that, over the range of temperatures and times tested, hot water scarification did not increase gorse seed germination.

Mechanical scarification utilises abrasion, particularly by rough surfaces, and is the most common treatment for impermeable seeds. Scarification can change the percentage of germinated seeds from less than $20 \%$ to more than $90 \%$ (Rolston 1978). However, in this case, germination after mechanical scarification was only $35 \%$.

Previous experiments have demonstrated that gorse seeds germinate under extreme heat (Zabkiewicz \& Gaskin 1978; McAlpine \& Timmins 2002). McAlpine \& Timmins (2002) found that gorse seed that had been exposed to dry high temperatures (up to $160^{\circ} \mathrm{C}$ for up to $10 \mathrm{~min}$ ) still germinated, with the most favourable temperature being $140^{\circ} \mathrm{C}$ for $5 \mathrm{~min}$ where there was $50 \%$ germination. However, the current experiment with hot water treatment did not find that the wet high temperatures caused more seed to germinate. This indicates that the gorse seed requires a higher temperature to break the hard shell than that provided by this hot water experiment.

In these experiments, seeds were taken from pods, which were picked from gorse bushes. As a result some seed may not have been fully mature despite the fact that only black pods were selected. This is reflected in the low (10\%) germination of unscarified seeds. Since mean germination rates of up to $81 \%$ were obtained for some scarification treatments, most of the seed used in these experiments (approximately 70\%) was hard. In previous work Ivens (1983) took gorse seed from the soil, collected seed from trays placed under gorse bushes and took seed from ripe pods. It was found that there was a higher proportion of hard seed in seed from pods than in seed collected from seed trays, and very little of the seed from the soil was hard.

The results from this experiment show that the best method of scarifying gorse seed was with concentrated sulphuric acid, giving $81 \%$ germination when the seed had been soaking in the acid for 180-210 min. The temperature that gave the best germination was $15^{\circ} \mathrm{C}$. This coincides with previous experiments on gorse seed (Ivens 1983) as well as other moderate legume shrubs (Wan Mohamed 1981; Tesfaye 1989). The methods that produced the best results in this experiment will be used in sample tests to calculate the percentage of viable gorse seeds throughout South Island, New Zealand.

\section{ACKNOWLEDGEMENTS}

We thank Ross Patching for the source of gorse pods, Mike Bowie for assistance in the laboratory and Richard Sedcole for statistical analysis.

\section{REFERENCES}

Butler, J.H.B. 1976: A preliminary investigation of the hard seed characteristics of Ulex europeaus with emphasis on laboratory scarification treatments. B. Ag. Sci. Honours Dissertation, Massey University, Palmerston North. 82 p.

Hartmann, H.T.; Kester, D.E.; Davies, F.T. Jr.; Geneve, R.L. 2002: Techniques of propagation by seed. In: Plant propagation, principles and practices 7 th edition. Prentice Hall, Upper Saddle River, New Jersey. Pp. 249-274.

Ivens, G.W. 1982: Seasonal germination and establishment of gorse. Proc. 35th N.Z. Weed and Pest Control Conf: : 152-156. 
Ivens, G.W. 1983: The influence of temperature on germination of gorse (Ulex europaeus L.). Weed Res. 23: 207-216.

McAlpine, K.; Timmins, S. 2002: The effect of fire on bone-seed and gorse germination. Science Poster No. 56. Department of Conservation, Wellington, New Zealand.

Moss, G.R. 1959: The gorse seed problem. Proc. 12th N.Z. Weed Control Conf.: 59-64.

Rolston, M.P. 1978: Water impermeable seed dormancy. Botanical Rev. 44:365-396.

Tesfaye, M. 1989: Morphometrics, characterization and seedling emergence studies of a collection of Russell lupin (Lupinus polyphyllus $\mathrm{x}$ Lupinus arboreus) genotypes in Canterbury. Masters thesis, Lincoln College, Lincoln University Library. 151 p.

Wan Mohamed, W.E. 1981: The potential for browse of a weedy shrub legume - a case study of broom (Cytisus scoparius L.). PhD thesis, Lincoln College, Lincoln University Library. 248 p.

Zabkiewicz, J.A. 1976: The ecology of gorse and its relevance to New Zealand Forestry. New Zealand Forest Service, Forest Research Institute, Symposium 18: 63-68.

Zabkiewicz, J.A.; Gaskin, R.E. 1978: Effect of fire on gorse seeds. Proc. 31st N.Z. Weed and Pest Control Conf.: 47-52. 